Rev. Bras. Saúde Prod. Anim., Salvador, v.15, n.3, p.592-603 jul./set., 2014 http://www.rbspa.ufba.br ISSN 15199940

\title{
Palm kernel meal as additive in the elephant-grass silage*
}

\author{
Farelo de dendê como aditivo em silagens de capim elefante
}

\author{
SANTOS, Ivan Alberto Palheta ${ }^{1}$; DOMINGUES, Felipe Nogueira ${ }^{2}$; RÊGO, Aníbal \\ Coutinho do ${ }^{3}$; SOUZA, Natália Sidrim da Silva de ${ }^{1}$; BERNARDES, Thiago Fernandes ${ }^{4}$; \\ BARATA, Zuleide Rafaela Pimentel ${ }^{5}$; MORAES, Carina Martins de ${ }^{2}$
}

\author{
${ }^{1}$ Faculdades Integradas Aparício Carvalho, Porto Velho, Rondônia, Brasil. \\ ${ }^{2}$ Universidade Federal do Pará, Castanhal, Pará, Brasil. \\ ${ }^{3}$ Universidade Federal Rural da Amazônia, Belém, Pará, Brasil. \\ ${ }^{4}$ Universidade Federal de Lavras, Lavras, Minas Gerais, Brasil. \\ ${ }^{5}$ Mestre em Zootecnia, Universidade Federal Rural da Amazônia, Belém, Pará, Brasil. \\ *E-mail para correspondência: ivan.santos15@gmail.com
}

\section{RESUMO}

Objetivou-se com este estudo avaliar o efeito da adição de farelo de dendê (BP) como aditivo na silagem de capim-elefante. A composição química e fermentação foram analisadas em delineamento experimental inteiramente casualizado, com seis tratamentos, sendo um sem BP (C) e seis repetições, em que as médias dos resultados dos dias de fechamento e abertura foram analisadas por análise de regressão. As amostras foram coletadas no momento da ensilagem e após 190 dias de armazenamento para avaliação da matéria seca, proteína bruta, carboidratos (total, não fibrosos, solúvel em água, celulose e hemicelulose), cinzas, lignina e extrato etéreo. $\mathrm{Na}$ fase aeróbia, foram coletadas amostras para $\mathrm{pH}$, nitrogênio amoniacal, fungos e leveduras. $\mathrm{O}$ capim-elefante do experimento apresentou valores de $13,9 \%$ de $\mathrm{MS}$ e $8,25 \%$ de PB, enquanto a BP tem $77,2 \%$ de MS e $16,9 \%$ de PB. A inclusão de $\mathrm{BP}$ inibiu o crescimento de fungos e leveduras. $\mathrm{O}$ aumento do teor de BP diminuiu a concentração de NH3-N. Maiores concentrações de BP tornaram as silagens mais estáveis, tendo sua quebra em 72 horas, enquanto que a estabilidade de $\mathrm{C}$ foi de 19 horas. As silagens com concentrações superiores a $15 \%$ BP não apresentaram variações significativas no $\mathrm{pH}$, na fase aeróbica. A inclusão de farelo de palma, em concentrações de $10 \%$ a $15 \%$ pode ser usado em silagem de elefante, inibindo fermentação indesejável e tornando-as mais estáveis. Concentrações acima deste valor podem afetar o valor nutritivo da silagem pelo alto teor de lignina do aditivo.

Palavras-chave: estabilidade aeróbia, Elaeis guineensis, fermentação, Pennisetum purpureum

\section{SUMMARY}

The objective of this study was to evaluate the effect of adding palm kernel meal (BP) as an additive in elephant grass silage. The chemical qualitative and fermentation were analysed in a completely randomized design with six treatments, one with no BP $(\mathrm{C})$ and six replications, where the averages of the results of days of closing and opening were analysed by regression analysis. We collected samples at the time of ensiling and after 190 days of storage for evaluation of dry matter, crude protein, carbohydrates (total, non-fibrous, water-soluble, cellulose and hemicellulose), ash, lignin and ether extract. In aerobic phase, we collected samples for $\mathrm{pH}$, ammoniacal nitrogen, fungi and yeasts. The elephant grass of this experiment showed values of $13.9 \% \mathrm{DM}$ and $8.25 \% \mathrm{CP}$ while the BP has $77.2 \% \mathrm{DM}$ and $16.9 \%$ $\mathrm{CP}$. The inclusion of BP had inhibited the growth of fungi and yeasts. The increase in the content of $\mathrm{BP}$ decreased the concentration of $\mathrm{NH}_{3}-\mathrm{N}$. Higher concentrations of BP in silage were more stable, and the stability breaks in 72 hours, while the stability of $\mathrm{C}$ was 19 hours. Concentrations above $15 \% \mathrm{BP}$ had no significant variations in $\mathrm{pH}$ in the aerobic phase. The inclusion of palm kernel meal at concentrations $10 \%$ to $15 \%$ can be used in silage of elephant grass, inhibiting undesired fermentation and making them more stable. Concentrations above this value may affect the nutritive value of silage by high lignin content of the additive.

Keywords: aerobic stability, Elaeis guineensis, fermentation, Pennisetum purpureum 


\section{INTRODUCTION}

One of the biggest problem faced by farmers is the seasonality forage at certain times of the year, where the level of animal productivity decreases due to feed deficiencies of good nutritional value.

The grasses of the genus Pennisetum present high production of herbage mass per hectare during the period of higher precipitation of water. This causes excess production and most often occurs underutilized grass. The ensiling process is to take advantage of this strategy over and use it, regardless of the purpose: the production of milk, meat or as a supplement in the diet during critical periods caused by adverse weather.

However, this process requires some features that should be considered to be a minimum of losses during its making. The dry matter content (DM) has great influence in the chemical reactions that occur during storage, affecting thus the nutritional value of the silage (BARNETT, 1954). McDonald et al. (1991) considers a content of about $25 \%$ of DM that does not harm the fermentation processes. The practice of including additives absorbing moisture appears as an option to assist in biochemical interactions resulting from ensiling process.

Currently, the use of agro-industrial byproducts appears as viable option for the farmer, especially for the cost and benefit of its use. In Pará, the annual yield of palm oil is about 27 thousand cubic meters of palm oil for biodiesel (EMBRAPA, 2010), and as a byproduct is extracted palm kernel meal that has been used in animal feed due to its availability and low cost. However, there is little scientific information about its characteristics as food and its effect on ensiling. There are few international studies that have used palm kernel meal in silage, and in Brazil there is no study on the subject, being necessary research that will enable their characterization and definition.

The objective of this work was to evaluate the effect of adding increasing concentrations of palm kernel meal (Elaeis guineensis) as additives sequestering moisture silage of elephant grass (Pennisetum purpureum).

\section{MATERIAL AND METHODS}

The experiment was conducted between May 2012 and June 2013 at the Federal University of Pará (UFPA), in the Faculty of Veterinary Sciences, located in the city of Belém/PA. The field phase trial lasted 240 days and this is understood by cutting levelling, preparation of experimental silos and silo opening. The forage used was the elephant grass (Pennisetum purpureum cv Cameron), harvested with $1.20 \mathrm{~m}$ high with about 45 days, the height of harvesting was based on studies from Wadi et al. (2004) which demonstrates that this height have the nutritional equilibrium with dry matter production. The grass was allocated in experimental silos in plastic buckets of $15 \mathrm{~kg}$. Compression was achieved using iron rods, and to quantify the mass was determined the volume of each silo experimental deducting the space occupied by sand and screen. After compaction of the forage, the silos were sealed with plastic caps and taped all around.

Table 1 shows the chemical composition of Palm kernel meal used in the experiment as an additive for elephant grass silage. 
Table 1. Chemical composition of palm kernel meal found in Pará

\begin{tabular}{|c|c|}
\hline Compounds & Palm kernel meal \\
\hline DM $\left(\right.$ g. $\left.100 g^{-1}\right)$ & 77.2 \\
\hline $\mathrm{CP}\left(\mathrm{g} .100 \mathrm{gDM}^{-1}\right)$ & 16.9 \\
\hline $\mathrm{ADF}\left(\mathrm{g} .100 \mathrm{gDM}^{-1}\right)$ & 48.9 \\
\hline $\mathrm{NDF}\left(\mathrm{g} .100 \mathrm{gDM}^{-1}\right)$ & 71.5 \\
\hline $\mathrm{EE}\left(\mathrm{g} .100 \mathrm{gDM}^{-1}\right)$ & 1.7 \\
\hline Ash (g.100DM $\left.{ }^{-1}\right)$ & 4.6 \\
\hline Cel (g.100DM $\left.{ }^{-1}\right)$ & 41.2 \\
\hline $\operatorname{Hem}\left(\right.$ g. $\left.100 \mathrm{DM}^{-1}\right)$ & 22.6 \\
\hline $\operatorname{Lig}($ g.100DM-1) & 7.7 \\
\hline $\operatorname{ADIN}\left(\mathrm{g} . \mathrm{N}\right.$ total $\left.^{-1}\right)$ & 3.4 \\
\hline $\mathrm{CHO}\left(\mathrm{g} .100 \mathrm{gDM}^{-1}\right)$ & 76.7 \\
\hline $\mathrm{NFC}\left(\mathrm{g} .100 \mathrm{gDM}^{-1}\right)$ & 12.9 \\
\hline WSC $\left(\mathrm{g} .100 \mathrm{gDM}^{-1}\right)$ & 0.9 \\
\hline \multicolumn{2}{|c|}{$\begin{array}{l}\text { DM = dry matter, } \mathrm{CP}=\text { crude protein, } \\
\text { NDF }=\text { neutral detergent fiber, ADF }=\text { acid } \\
\text { detergent fiber, EE = ether extract, Cel }= \\
\text { cellulose, hemicellulose }=\text { Hem, Lig = } \\
\text { lignin, ADIN = acid detergent insoluble } \\
\text { nitrogen, CHO = carbohydrates, NFC = } \\
\text { non-fiber carbohydrates, WSC = water } \\
\text { soluble carbohydratesSource: Analysis of } \\
\text { field data, } 2012\end{array}$} \\
\hline
\end{tabular}

Each silo behaved between $13-15 \mathrm{~kg}$ of elephant grass (with or without additives), with screen and $2 \mathrm{~kg}$ of sand, with the compression of $668.31 \pm$ $37.70 \mathrm{~kg} / \mathrm{m}^{3}$ of natural raw.

Treatments were composed of increasing concentrations of palm kernel meal based on natural raw elephant grass. The treatments were:

C: $0 \%$ (no added palm kernel meal control); BP5\%: 95\% elephant grass, 5\% palm kernel meal; BP10\%: $90 \%$ elephant grass, $10 \%$ palm kernel meal; BP15\%: $85 \%$ elephant grass, $15 \%$ palm kernel meal; BP20\%: 80\% elephant grass, $20 \%$ palm kernel meal; BP25\%: $75 \%$ elephant grass, $25 \%$ palm kernel meal.

To determine the loss of dry matter (LDM) we used an adaptation to the equation described by Jobim et al. (2007), the loss of gasses (LG) were estimated by the difference in gross weight of the experimental silos, silage and on the opening date. The determination of gas loss was calculated by the equation described by Siqueira et al., (2007). The determination of effluent production (EP) was calculated by the equation described by Siqueira et al. (2007).

Representative samples were taken from the elephant grass, palm kernel meal and from each treatment before the closing of the silos, and on opening day, for chemical, qualitative analyses. On days $0,3,6$ and 9 were analysed for microbiological aerobic and aerobic stability.

Samples were pre-dried in a forced circulation oven at $55^{\circ} \mathrm{C}$ for three days (to stabilize its weight) and milled after sieve $1 \mathrm{~mm}$ in a Wiley mill type. The content of dry matter (DM) and crude protein $(\mathrm{CP})$, ash and ether extract (EE) were analysed according to Association of Official Analytical Chemists (1995). The contents of neutral detergent fiber (NDF) and acid detergent fiber (ADF) were determined by sequential method by Van Soest et al., (1991) using the apparatus analyser fiber without adding $\alpha$-amylase and sodium sulphite, lignin was obtained by extraction with $72 \%$ $\mathrm{H}_{2} \mathrm{SO}_{2}$ and subsequently the measurement was taken of this lignin to obtain values of cellulose, hemicellulose and lignin, with the ashes corrected. Compounds acid detergent insoluble nitrogen (ADIN) were determined according to Licitra et al. (1996).

The water soluble carbohydrates (WSC) were extracted with $80 \%$ ethanol and determined by the anthrone method (DISCHE, 1962). The results were expressed in g. $100 \mathrm{gDM}^{-1}$. The total carbohydrate $(\mathrm{CHO})$ were determined by the following equation: $100-(\% \mathrm{CP}$ 
$+\% \mathrm{EE}+\%$ Ash), according to Sniffen et al. (1992). The non-fibrous carbohydrates were determined by the difference of the $\mathrm{CHO}$ and NDFap, where NDFap is NDF corrected for ash and protein.

In addition to the analyses described, aliquots of aerobic treatments were sampled to obtain the aqueous extract for $\mathrm{pH}$ and ammoniacal nitrogen $\left(\mathrm{NH}_{3}-\right.$ $\mathrm{N}$ ), according to the methodology described by Tabacco et al. (2009).

After the opening of the experimental silos were removed from each sample unit to be packaged in smaller silos. On days $0 ; 3 ; 6$ and 9 were sampled for microbial count.

Microbiological analyses were carried out at the Microbiology Laboratory of the Federal University of Pará. Therefore, were weighed $25 \mathrm{~g}$ silage and added $225 \mathrm{~mL}$ of saline peptone at $0.1 \%$ for counting fungi and yeast according to Normative Instruction 62 (BRASIL, 2003). Dilutions were made from $10^{-1}$ to $10^{-7}$ and from these dilutions, the seedlings performed in triplicate in petri dishes with culture medium potato dextrose agar with correction for $\mathrm{pH} 4$, by means of tartaric acid and soon after incubated aerobically for 72 hours at room temperature.

To determine the aerobic stability from the time of opening of the silo at the 190th day we inserted into a data logger inside the mass on each bucket to determine the temperature, and four devices were placed near the buckets to evaluate ambient temperature for ten days.

The aerobic stability was considered as the time required to achieve mass $2^{\circ} \mathrm{C}$ above room temperature (KUNG JUNIOR et al., 1984). The data loggers were programed for analysis of temperature in every 30 minutes.

The chemical (DM, ASH, CP, ADIN, CHO, NFC, WSC, EE, cellulose, hemicellulose and lignin) and fermentation (density, EP, LDM, LG, $\mathrm{pH}$ and $\mathrm{NH}_{3}-\mathrm{N}$ ) were analysed in experiments randomized design with six treatments and six replications where the average results of the day of closing and opening day were analysed by regression analysis using the software SAS (STATISTICAL ANALYSIS SYSTEM, 2001).

The experiment used a split-plot, so that treatments (concentrations of palm kernel meal) were randomized to the plots and evaluation times $(0 ; 3 ; 6$ and 9 days in aerobic environment) subplots. Data were analysed statistically by analysis of variance procedures suggested by Steel et al. (1997) with dismemberment of the regression curves for treatment in the experiments in split plot when plots are measured in time, using software SAS (Statistical Analysis System, 2001).

\section{RESULTS AND DISCUSSION}

The Chemical characteristics before ensiling are shown at Table 2 and Table 3 demonstrates the chemical characteristics of the treatments at the opening of the silos

The inclusion of $\mathrm{BP}$ increased significantly $(\mathrm{P}<0.05)$ for $\mathrm{DM}, \mathrm{CP}$, NDF, ADF, Lig, NIDA and EE.

BP notoriously had lower density and elephant grass in this experiment, to obtain the $25 \%$ dry - matter claimed by McDonald (1981), it was necessary to include $19.26 \%$ of BP, yielding a density of $642.02 \mathrm{~kg} / \mathrm{m}^{3}$. The DM content in treatments with concentrations less than $19.25 \%$ of BP are below the $25 \%$ recommended by McDonald et al. (1991) as a prerequisite for silage effluent has minimum loss and hence the retention of nutrients occurs in silage. 
In $\mathrm{CP}, \mathrm{NDF}$ and ADF decreased sharply on values found in elephant grass (Table 2) compared with the levels found in the silage at the opening (Table 3). Unlike what happened with the values of NIDA, given that the levels increased significantly after the fermentation period.

The increase of the BP content conserved $\mathrm{CP}$ present in the silage more efficiently in the treatment BP5\%, BP10\% and BP15\%, which preserved $97 \%, 85 \%$ and $83 \%$ of $\mathrm{CP}$, respectively, the $\mathrm{C}$ treatment, and $\mathrm{BP} 20 \% \mathrm{BP} 25 \%$ preserved only $77 \%, 75 \%$ and $73 \%$ respectively, it is assumed that these losses were digestible protein, as ADIN representing the indigestible protein showed higher values. The high values of $\mathrm{NH}_{3}-\mathrm{N}$, also may explain the decrease of the values of $\mathrm{CP}$, where the ammonia is a by-product of proteolysis caused by unwanted organism present in moist environments.

The increase of both Lig, NDF and ADF in the opening of the silos were given the loss of soluble components DM in the effluent, which increases the levels of these components (McDonald, 1981).

Reducing the amount of digestible protein in the substrate due to the change in $\mathrm{NH}_{3}-\mathrm{N}$ is one of the determining factors for the increase indirect ADIN. Another key factor in achieving this effect was warm naturally occurring due metabolism of the silage, since this procedure slightly decreases the digestibility by increasing the levels of NIDN and ADIN (Van SOEST, 1994). The increase in the content of ADIN is not desirable because the nitrogen attached to the ADF is not used by ruminal bacteria.

Increasing concentrations of the additive, the levels of WSC decreased in treatments because the BP has lower concentration of WSC that the elephant grass. However, the values were well below those found in the opening, which demonstrates that the WSC was consumed by the microorganisms which developed during the fermentation process.

The values of WSC differed in the time of ensiling (Table 2), which is justified by the lower concentration of WSC in BP, however, at the end of the fermentation period, no significant differences were found (Table 3). The highest values of WSC in silages with lower concentrations of BP explain why the $\mathrm{pH}$ found in these treatments were lower than that found in treatments with higher concentrations of BP because the WSC is an essential nutrient for the development of lactic acid bacteria, which produce lactic acid, so the treatments with higher concentrations of WSC had lower $\mathrm{pH}$ compared to treatments with lower levels of WSC. As included $1 \%$ BP, lost about $0.43 \%$ of WSC.

WSC values were lower in treated inclusions with higher BP concentrations (Table 2). At the opening of the silos values WSC showed no significant differences (Table 3). Table 3 presents the results of chemical composition of the silages after 190 days of fermentation. In the variables DM, CP, NDF, ADF, Lig, and NIDA observed difference among treatments $(\mathrm{P}<0.05)$. The maximum $\mathrm{DM}$ were found in the treatments with greater inclusion of BP. The levels of CEL, HEM, WSC, ASH and EE showed no significant difference $(\mathrm{P}>0.05)$ between treatments.

The EE showed little increase in their values in silages compared with the forage (Table 2). 
Table 2. Density and chemical composition of silage at the time of ensiling

\begin{tabular}{|c|c|c|c|c|c|c|c|c|}
\hline Variable & $\mathrm{BP}$ & BP5\% & BP10\% & BP15\% & BP20\% & BP25\% & Equation & $\mathrm{R}^{2}$ \\
\hline $\mathrm{DEN}\left(\mathrm{kg} / \mathrm{m}^{3}\right)$ & 722,6 & 701,3 & 671,5 & 646,3 & 638,4 & 629,4 & $Y=716,87-3,8866 x$ & 0,83 \\
\hline $\mathrm{DM}\left(\mathrm{g} .100 \mathrm{~g}^{-1}\right)$ & 13,9 & 16,9 & 17,0 & 22,0 & 25,7 & 29,2 & $Y=13,15+0,6153 x$ & 0,98 \\
\hline $\mathrm{CP}\left(\mathrm{g} .100 \mathrm{gDM}^{-1}\right)$ & 8,25 & 8,56 & 10,9 & 12,0 & 13,7 & 15,4 & $\mathrm{Y}=7,8+0,2898 \mathrm{x}$ & 0,98 \\
\hline $\mathrm{NDF}\left(\mathrm{g} .100 \mathrm{gDM}^{-1}\right)$ & 70,25 & 70,87 & 74,27 & 74,34 & 74,34 & 75,33 & $\mathrm{Y}=70,67+0,205 \mathrm{x}$ & 0,82 \\
\hline $\mathrm{ADF}\left(\mathrm{g} .100 \mathrm{gDM}^{-1}\right)$ & 41,26 & 44,26 & 44,96 & 45,10 & 46,83 & 47,42 & $\mathrm{Y}=42,211+0,2209 \mathrm{x}$ & 0,89 \\
\hline $\mathrm{Cel}\left(\mathrm{g} .100 \mathrm{gDM}^{-1}\right)$ & 39,2 & 41,3 & 43,18 & 43,8 & 43,7 & 45,0 & $Y=1,331-0,1565 x$ & 0,68 \\
\hline $\mathrm{Hem}\left(\mathrm{g} .100 \mathrm{gDM}^{-1}\right)$ & 28,0 & 27,5 & 25,9 & 25,3 & 24,6 & 24,2 & $Y=1,989-0,1615 x$ & 0,48 \\
\hline $\operatorname{Lig}\left(\mathrm{g} .100 \mathrm{gDM}^{-1}\right)$ & 3,04 & 5,01 & 5,19 & 5,78 & 6,04 & 6,11 & $Y=0,4132+2,9562 x$ & 0,75 \\
\hline ADIN (\%N-total) & 2,48 & 2,82 & 3,12 & 3,36 & 3,68 & 3,88 & $Y=2,5219+0,0561 x$ & 0,97 \\
\hline $\mathrm{CHO}\left(\mathrm{g} .100 \mathrm{gDM}^{-1}\right)$ & 85,1 & 85,4 & 83,4 & 82,6 & 80,7 & 79,4 & $Y=89,925-0,2484 x$ & 0,83 \\
\hline $\mathrm{NFC}\left(\mathrm{g} .100 \mathrm{gDM}^{-1}\right)$ & 21,8 & 17,7 & 17,5 & 16,8 & 14,9 & 15,0 & $Y=20,362-0,2463 x$ & 0,84 \\
\hline WSC (g.100gDM $\left.{ }^{-1}\right)$ & 7,36 & 4,27 & 3,69 & 2,79 & 2,46 & 1,95 & $Y=6,1406-0,1909 x$ & 0,93 \\
\hline Ash $\left(\mathrm{g} .100 \mathrm{gDM}^{-1}\right)$ & 6,50 & 5,91 & 5,54 & 5,29 & 5,42 & 5,10 & $Y=6,2487-0,0497 x$ & 0,62 \\
\hline $\mathrm{EE}\left(\mathrm{g} .100 \mathrm{gDM}^{-1}\right)$ & 1,64 & 1,62 & 1,65 & 1,69 & 1,79 & 1,84 & $Y=1,5943+0,0089 x$ & 0,85 \\
\hline
\end{tabular}

All results showed $\mathrm{P}<0.05$; Legend DEN $=$ density, $\mathrm{DM}=$ dry matter, $\mathrm{CP}=$ crude protein, Cel $=$ cellulose, hemicellulose $=\mathrm{Hem}, \mathrm{Lig}=$ lignin, $\mathrm{ADIN}=$ acid detergent insoluble nitrogen, $\mathrm{CHO}=$ carbohydrate total, $\mathrm{NFC}=$ non-fiber carbohydrates, $\mathrm{WSC}=$ water soluble carbohydrates, ash and EE $=$ ether extract. Source: Analysis of field data, 2012

Table 3. Chemical characteristics of the treatments at the opening of the silos

\begin{tabular}{|c|c|c|c|c|c|c|c|c|}
\hline Variable & BP & BP5\% & BP10\% & BP15\% & BP20\% & BP $25 \%$ & Equation & $\mathrm{R}^{2}$ \\
\hline $\mathrm{DM}\left(\mathrm{g} .100 \mathrm{~g}^{-1}\right)^{*}$ & 15,2 & 16,8 & 17,6 & 21,8 & 25,6 & 31,8 & $Y=15,443+0,3102 x$ & 0,41 \\
\hline $\mathrm{CP}\left(\mathrm{g} .100 \mathrm{gDM}^{-1}\right)^{*}$ & 6,37 & 8,45 & 9,28 & 9,96 & 11,6 & 10,9 & $Y=7,0776+0,1885 x$ & 0,61 \\
\hline $\mathrm{NDF}\left(\mathrm{g} .100 \mathrm{gDM}^{-1}\right)^{*}$ & 64,9 & 71,9 & 76,7 & 74,7 & 76,1 & 77,2 & $Y=69,653+0,3923 x$ & 0,58 \\
\hline $\operatorname{ADF}\left(\text { g. } 100 \mathrm{gDM}^{-1}\right)^{*}$ & 43,9 & 46,8 & 52,4 & 50,9 & 52,9 & 53,3 & $Y=45,514+0,3624 x$ & 0,64 \\
\hline $\operatorname{Cel}\left(\mathrm{g} .100 \mathrm{gDM}^{-1}\right)$ & 41,04 & 43,34 & 47,06 & 45,03 & 46,2 & 47,1 & NS & -- \\
\hline $\operatorname{Hem}\left(\mathrm{g} .100 \mathrm{gDM}^{-1}\right)$ & 23,8 & 25,1 & 24,3 & 23,8 & 23,2 & 23,9 & NS & -- \\
\hline $\operatorname{Lig}\left(\mathrm{g} .100 \mathrm{gDM}^{-1}\right)^{*}$ & 3,38 & 5,43 & 5,54 & 5,87 & 6,08 & 6,20 & $Y=0,2342+0,3523 x$ & 0,78 \\
\hline $\operatorname{ADIN}(\% \mathrm{~N} \text { total })^{*}$ & 12,2 & 12,5 & 14,1 & 15,4 & 15,9 & 16,8 & $Y=9,8671+0,2542 x$ & 0,19 \\
\hline WSC (g.100gDM $\left.{ }^{-1}\right)$ & 0,78 & 1,11 & 0,60 & 0,94 & 0,83 & 0,77 & NS & -- \\
\hline Ash $\left(\mathrm{g} .100 \mathrm{gDM}^{-1}\right)$ & 7,23 & 7,40 & 7,21 & 7,27 & 7,60 & 7,37 & NS & -- \\
\hline $\mathrm{EE}\left(\mathrm{g} .100 \mathrm{gDM}^{-1}\right)$ & 2,00 & 2,03 & 2,60 & 2,37 & 2,72 & 2,67 & NS & -- \\
\hline
\end{tabular}

$* \mathrm{P}<0.05$, NS - Not significant, DM = dry matter, $\mathrm{CP}=$ crude protein, Cel = cellulose, hemicellulose = Hem, Lig = lignin, ADIN = acid detergent insoluble nitrogen, $\mathrm{WSC}=$ water soluble carbohydrates, ASH = ash, EE = ether extract. Source: Analysis of field data, 2012. 
Fermentation characteristics, losses and microbial count of elephant grass silages treated with different concentrations of BP after 190 days of fermentation are shown in Table 4. Thus the regression analyses showed significance for the content of LG and Fun estimating quadratic equations. Variables LDM, EP, $\mathrm{pH}$ and $\mathrm{NH}_{3}-\mathrm{N}$ varied significantly in linear equations. Yeasts in the regression was not significant $(\mathrm{P}>0.05)$.

Table 4. Characteristics fermentative, losses and microbial count of elephant grass silages treated with different inclusion levels of palm kernel meal (BP) at the opening of the silos

\begin{tabular}{|c|c|c|c|c|c|c|c|c|}
\hline Variable & $\mathrm{BP}$ & $\begin{array}{l}\text { BP } \\
5 \%\end{array}$ & $\begin{array}{c}\mathrm{BP} \\
10 \% \\
\end{array}$ & $\begin{array}{c}\mathrm{BP} \\
15 \%\end{array}$ & $\begin{array}{c}\mathrm{BP} \\
20 \% \\
\end{array}$ & $\begin{array}{c}\text { BP } \\
25 \%\end{array}$ & Equation & $\mathrm{R}^{2}$ \\
\hline $\operatorname{LDM}\left(\mathrm{g} .100 \mathrm{gDM}^{-1}\right)^{*}$ & 9,83 & 7,73 & 5,97 & 5,46 & 4,95 & 3,61 & $Y=9,7968-0,2375 x$ & 0,74 \\
\hline $\mathrm{LG}\left(\mathrm{g} .100 \mathrm{gDM}^{-1}\right)^{*}$ & 4,40 & 4,00 & 5,64 & 5,16 & 2,82 & 3,67 & $Y=4,2534+0,1289 x-0,0068 x^{2}$ & 0,29 \\
\hline $\mathrm{EP}\left(\text { Kg.ton } \mathrm{NM}^{-1}\right)^{*}$ & 44,6 & 42,0 & 27,3 & 28,1 & 10,4 & 5,31 & $\mathrm{Y}=47,056-1,6601 \mathrm{x}$ & 0,69 \\
\hline $\mathrm{pH}^{*}$ & 3,63 & 4,24 & 4,39 & 4,71 & 4,81 & 4,88 & $Y=3,8519+0,0473 x$ & 0,98 \\
\hline $\mathrm{NH}_{3}-\mathrm{N}(\% \text { of total } \mathrm{N})^{*}$ & 11,7 & 12,6 & 11,4 & 5,67 & 4,41 & 1,93 & $Y=13,677-0,4558 x$ & 0,97 \\
\hline Fun $\left(\log \text { CFU.g }{ }^{-1}\right)^{*}$ & 2,03 & 3,04 & 3,17 & 3,34 & 1,84 & 1,00 & $Y=2,0775+0,2326 x-0,0113 x^{2}$ & 0,75 \\
\hline yeast $\left(\log\right.$ CFU.g $\left.{ }^{-1}\right)$ & 1,81 & 2,62 & 2,52 & 2,47 & 2,88 & 1,00 & NS & NS \\
\hline
\end{tabular}

$* \mathrm{P}<0.05 ; \mathrm{NS}$ - Not significant

$\mathrm{NM}=$ Natural matter, $\mathrm{CFU}=$ colony formation unit, $\mathrm{LDM}=$ Loss of dry matter, $\mathrm{LG}=$ Loss gases, EP = Production effluent $\mathrm{NH}_{3}-\mathrm{N}=$ ammoniacal nitrogen, Fun = fungi, and yeasts. Source: Analysis of field data, 2012.

There was a quadratic response for all treatments for the variables Yeasts, Fun and Temperature. When using the BP, it was noted linear decrease in the production of $\mathrm{NH}_{3}-\mathrm{N}$. On the last day of aerobic conditions (day 9), it was noted that the yeast count had the highest value in the treatment without the additive followed by treatment with less inclusion of BP.

The addition of the BP yielded smaller DM losses, this was because BP has greater DM value and lignin, which according to Jones \& Jones (1995) the ability to retain moisture additives absorbent may vary with the type of material used, noting that materials with higher lignification have higher water retention ability. However, according to these authors, though highly absorbent, these additives reduce the nutritive value of silage.

The $\mathrm{pH}$ of the treatment at the time of opening of the silo increased according to the concentration of the BP, values ranged from 3.63 in $\mathrm{C}$ to $4.88 \%$ in BP25\%, in addition, showed a good appearance and smell. According to Van Soest (1994) in silage with high $\mathrm{DM}$ content, the $\mathrm{pH}$ is less important, good quality can be obtained even at higher pH. Whittenbury et al. (1967) demonstrated that, evaluating the $\mathrm{pH}$ isolated, it becomes a less important parameter, because to consider a good quality silage, the $\mathrm{pH}$ should decrease rapidly to avoid the immediate production of $\mathrm{NH}_{3}-\mathrm{N}$ and butyric acid. In silage, low content of ammoniacal nitrogen $\left(\mathrm{NH}_{3}-\mathrm{N}\right)$, less than $10 \%$ of total nitrogen $(\mathrm{TN})$, indicates that the fermentation process did not result in excessive breakdown of protein into ammonia (VAN SOEST, 1994). In contrast, $\mathrm{NH}_{3}-\mathrm{N}$ concentration exceeding $15 \%$ NT means the breakdown of proteins was high, that silage can be rejected by the animals, resulting in low consumption. The concentration of $\mathrm{NH}_{3}-\mathrm{N}$ also indicates the activity of 
bacteria of the genus Clostridium, because this compound is produced in small quantities by other microorganism and enzymes from plants (McDonald, 1981).The values found in this experiment were considered good, values below $10 \%$ were observed in treatments with higher inclusions of BP $(15 \%, 20 \%$ and $25 \%$ ).

The higher values of $\mathrm{NH}_{3}-\mathrm{N}$ in the treatments with lower concentrations of $\mathrm{BP}$ demonstrated that even with low $\mathrm{pH}$ did not inhibit the bacteria of the genus Clostridium, which have their optimal growth in moisture content above $72 \%$ and a $\mathrm{pH}$ of around 5, but it is possible their growth in silage having problem to stabilize (McDonald et al., 1991).

Count yeast, filamentous fungi, temperature, $\mathrm{pH}$ and $\mathrm{NH} 3-\mathrm{N}$ in the elephant grass silages with increasing inclusion of palm kernel meal after silo opening are shown at Figure 1.

The $\mathrm{C}$ treatment also had the highest values for filamentous fungi and $\mathrm{pH}$ (Figure 1). The variable $\mathrm{pH}$, it was found that the treatments with inclusion of $\mathrm{BP}$ higher than $15 \%$ did not change significantly $(\mathrm{P}>0.05)$ during aerobic conditions.

The microorganism that initiate the attack on organic acids and are the most responsible for aerobic deterioration of silage are yeasts (PAHLOW et al., 2003). Many species of yeasts degrade lactic acid, causing the $\mathrm{pH}$ of the silage and provided conditions for other spoilage microorganism develop (McDonald et al., 1991). This explains the faster growth of the yeast population at the beginning of the aerobic process.

Regression analysis of yeast counts (yeast), filamentous fungi (Fun), temperature, $\mathrm{pH}$ and ammonia $\left(\mathrm{NH}_{3}-\mathrm{N}\right)$, during aerobic conditions are shown in Figure 1. The count of yeasts and filamentous fungi showed reduced values in silages with inclusion of more than $15 \%$ of BP (Figure 1).

Filamentous fungi grow best under aerobic conditions and higher $\mathrm{pH}$ (5.0 to $6.0)$. Thus, when the silo is opened, there is an increase in $\mathrm{pH}$ and oxygen concentration allowing the growth of these microorganism capable of degrading wide variety of nutrients, including structural carbohydrates and lignin. Thus, the degradation of complex compounds can release substrates for lactic acid bacteria and yeast to continue to grow (WINTERS et al., 1987).

The temperature elevation and its maintenance over time were important indicators of aerobic deterioration being due to the growth of yeasts and filamentous fungi.

Figure 2 shows the difference in temperature inside the silo and the environment and indication of the breakdown of the aerobic stability of silage elephant grass with increasing addition of BP after opening. The highest temperature during the aerobic treatments were $\mathrm{C}$, and $\mathrm{BP} 5 \%$ and $\mathrm{BP} 10 \%$ respectively. The treatments that had broken stability later were $\mathrm{BP} 15 \%$, BP20\% and BP25\% \% both with 72 hours, making them more stable than the others. The $\mathrm{C}$ treatment was the most unstable, breaking its stability at 19 hours after silo opening, followed by BP5 \% (27 hours) and BP10\% (29 hours).

The aerobic stability of silage can be defined as the resistance of the mass of material degradation after opening the silo. Some authors define as the time it takes for the silage to a temperature higher than $2{ }^{\circ} \mathrm{C}$ above room temperature (KUNG JUNIOR et al., 1984) or the accumulation of temperature during the days when the silage is exposed to air. The rapid metabolism of yeast during the first hours and the aerobic environment facilitated the development of other spoilage microorganism caused the 
Rev. Bras. Saúde Prod. Anim., Salvador, v.15, n.3, p.592-603 jul./set., 2014 http://www.rbspa.ufba.br ISSN 15199940

temperature varied significantly in the first few hours of aerobic, in particular to treatments with concentrations less than $15 \% \mathrm{BP}$.

The breakdown of stability was influenced by the addition of BP silage. The highest concentration of DM treatments made silages took longer to break aerobic stability, as higher values of DM hampered the growth of

$C: Y=1,7487+0,6989 x-0,0208 x^{\prime} \cdot R^{2}=0,9824 \quad B P 15 \%: Y=2,5268+0,0289 x+0,0267 x^{2} \cdot R^{2}=0,9997$ BPSX:Y $Y=2,5244+0,7225 x-0,0414 x^{2} \cdot R^{2}=0,9815 \quad B P 20 \%: Y=3,0989-0,1587 x+0,0401 X^{2} R^{2}=0,866$ BP10\%:Y $Y=2,3596-0,365 x+0,0357 x^{2} R^{2}=0,0956 \quad B P 25 \%: Y=1,1361+0,632 x-0,0161 x^{2} R^{2}=0,9668$

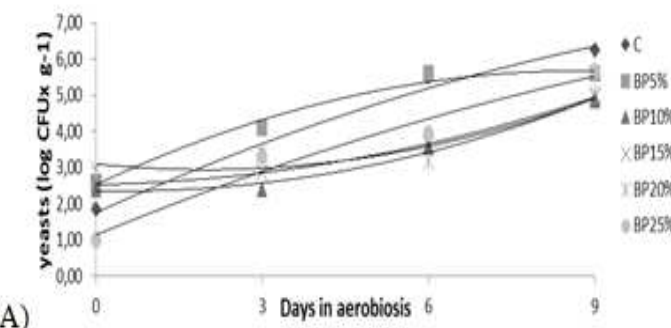

A)

$C: Y=2,0845+0,9182 x-0,0498 x^{\prime} R^{2}=0,9913 \quad B P 15 \% Y Y=3,4651 \cdot 0,0033 x+0,0226 x^{\prime} R^{2}=0,8158$ BPS $: Y=2,9958+0,4716 x-0,0222 x^{\prime} \cdot R^{2}=0,9868 \quad$ BP20\% $Y=1,8915+0,1432 x+0,0281 x^{2} R^{2}=0,9966$ BP10\%: $Y=3,2053-0,0172 x+0,0263 x^{2} R^{2}=0,9859 \quad B P 25 \%: Y=1,0333+0,4671 x-0,0125 x^{2} R^{2}=0,9961$

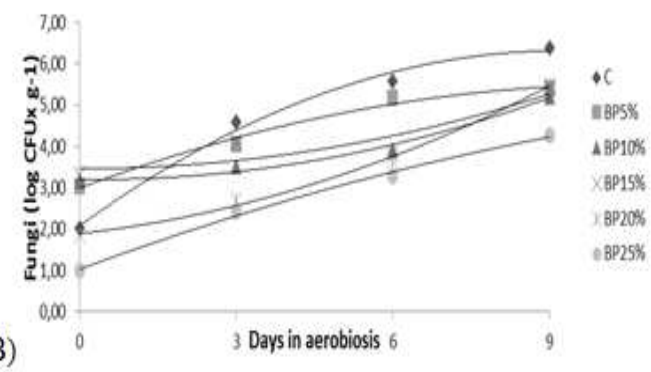

microorganism, lack of adequate moisture (BATISTA et al., 2006).

The amplitude of the temperature variation of the silo was quite high in treatments with less of $15 \%$ of $\mathrm{BP}$, reaching a peak of $7.2^{\circ} \mathrm{C}$ above the temperature at $5 \%$ inclusion, which could infer that there was intense microbial activity at this time.
$C: Y=29,401+5,0203 \cdot 0,3939 \times \cdot R^{2}=0,9535 \quad B P 15 \%: Y=30,785+0,0417 x+0,0017 \times \cdot R^{2}=0,855$

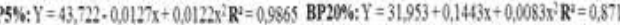
$B P 10 \%: Y=31,657 \cdot 0,051 x+0,0539 x^{2} \cdot R^{2}=0,9856 \quad B P 25 \%: Y=30,955+0,035 x+0,0083 x^{2} \cdot R^{3}=0,9333$

C)
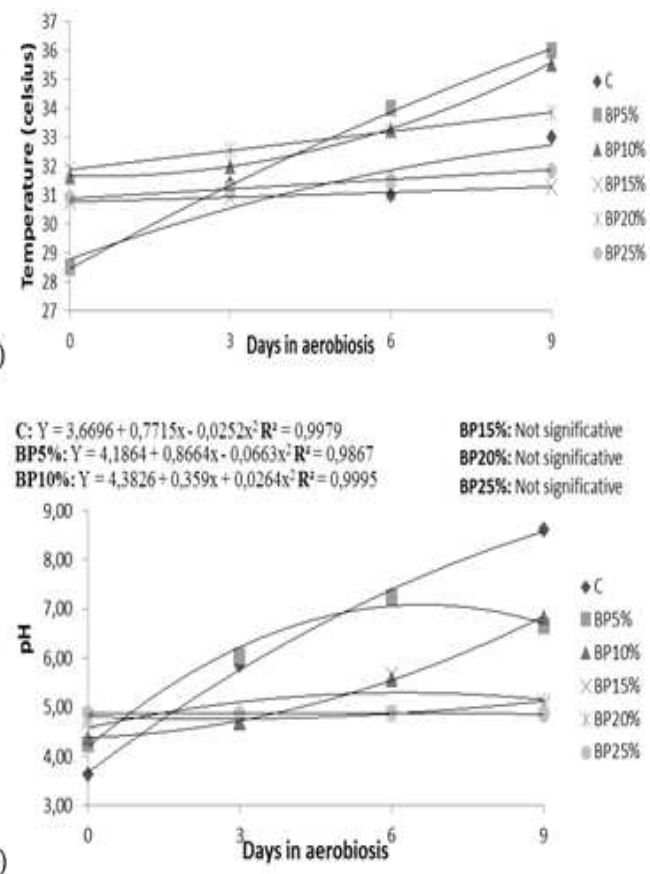

D)

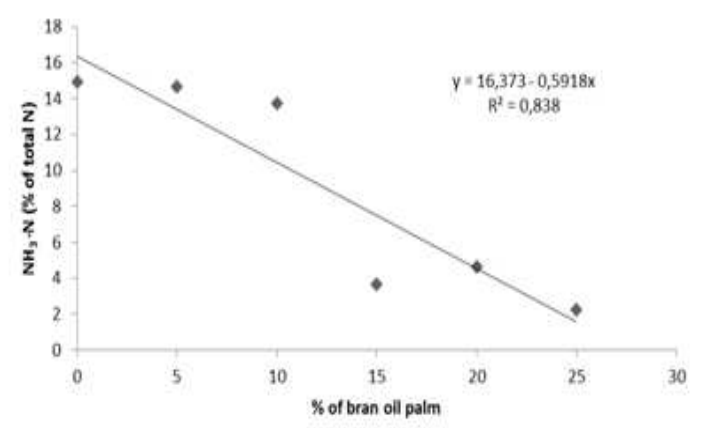

E)

Source: Field data, 2012

Figure 1. Count yeast (A), filamentous fungi (B), temperature (C), $\mathrm{pH}(\mathrm{D})$ and $\mathrm{NH}_{3}-\mathrm{N}$ (E) in the elephant grass silages with increasing inclusion of palm kernel meal (BP) after silo opening 


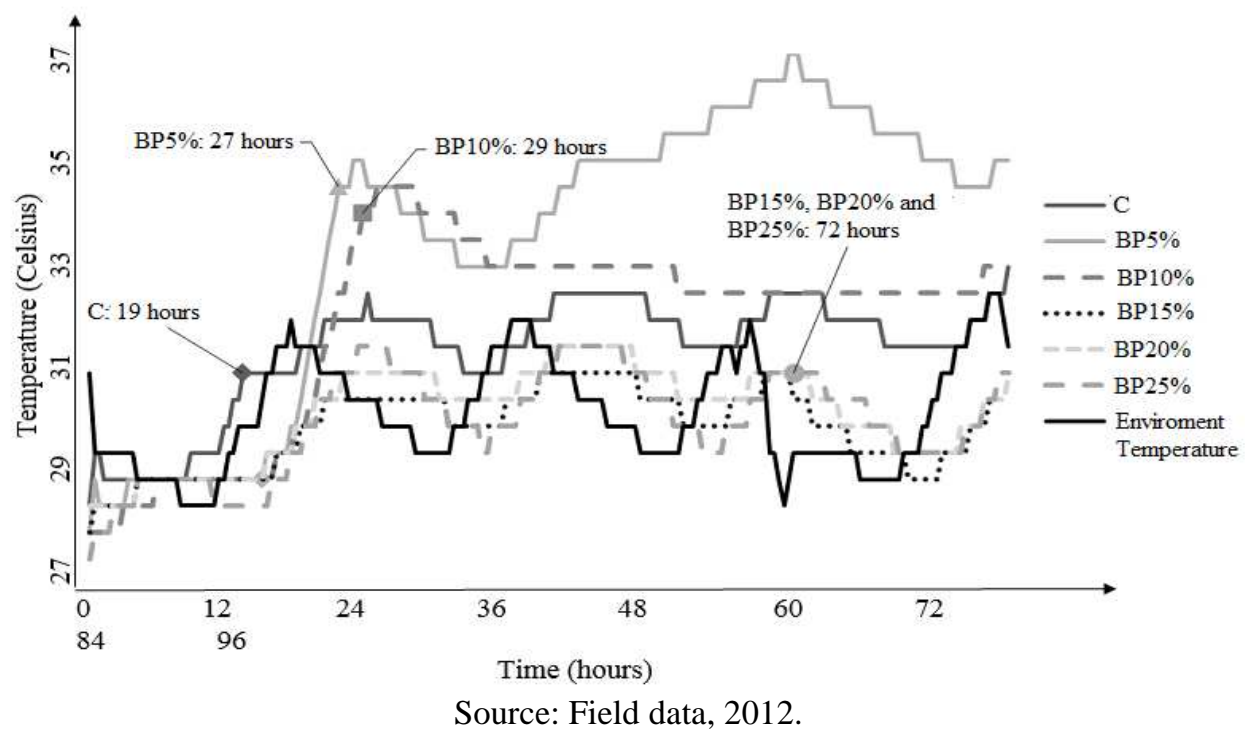

Figure 2. Temperature difference silo with temperature and an indication of the breakdown of aerobic stability of elephant grass silage with increasing additions of palm kernel meal $(0 \%, 5 \%, 10 \%$, $15 \% ; 20 \%$ and $25 \%$ ) after opening the silos

Treatment with lower levels of BP had higher concentration of WSC resulting in lower $\mathrm{pH}$ values because the microorganism produced greater amounts of organic acids, including lactic acid serving as a substrate for spoilage microorganism during aerobic conditions, causing the $\mathrm{pH}$ to rise again and have a greater proliferation of fungi and yeasts, causing heat generation. It was noted that the treatments with inclusion of more than $15 \% \mathrm{BP}$, despite the temperature variation, showed no significant changes in $\mathrm{pH}$ during the aerobic period evaluated. The higher concentration of DM silages with values above $15 \%$ of $\mathrm{BP}$ and the absence of change in $\mathrm{pH}$, inhibit the growth of bacteria of the genus Clostridium, microorganism responsible for the main metabolizing protein $\mathrm{NH}_{3}-\mathrm{N}$, and the larger was the addition of BP, the lower the concentration of $\mathrm{NH}_{3}-\mathrm{N}$ found. The inclusion of palm kernel meal in concentrations between $10-15 \%$ can be used in elephant grass silage, inhibiting undesired fermentation, reducing losses of DM and making them more stable. Concentrations above this value may affect the nutritive value of silage because of the high lignin content of the additive.

\section{ACKNOWLEDGMENTS}

To Heloísa Helena de Siqueira, who helped us on the chemical analysis stage in Lavras, to Federal University of Lavras for the infrastructure set for analysis and to Higor Rocha that gave me Bran Palm samples.

\section{REFERENCES}

ASSOCIATION OF OFFICIAL ANALYTICAL CHEMISTS - AOAC. Official Methods of Analysis. 16. ed. Washington DC, 1995.

BARNETT, A.J.G. Silage

fermentation. London: Butterworths Sci. Publ., 1954. 
BATISTA, A.M.V.; GUIM, A.; SOUZA, I.S.; LIRA, K.G.; SANTOS, M.V.F. dos. DUBEX JUNIOR, J. C. B. Efeitos da adição de vagens de algaroba sobre a composição química e a microbiota fúngica de silagens de capim-elefante. Revista Brasileira de Zootecnia, v.35, n.1, p.1-6, 2006.

BRASIL. Ministério da Agricultura, Pecuária e Abastecimento. Instrução Normativa n62. Brasília, 2003.

DISCHE, Z. General color reactions. In: WHISTLER, R.L.; WOLFRAM, M.L. ed. Carbohydrate chemistry. New York, Academic Press, 1962. p.477512.

\section{EMBRAPA. Zoneamento} agroecológico do dendezeiro para as áreas desmatadas da Amazônia Legal. Relatório Síntese. Rio de Janeiro, 2010. 44p.

JOBIM, C.C., NUSSIO, L.G., REIS, R.A., SCHMIDT, P Avanços metodológicos na avaliação da qualidade da forragem conservada.

Revista Brasileira de Zootecnia, v.36, p.101-119, 2007. Suplemento especial.

JONES, D.I.H.; JONES, R. The effect of crop characteristics and ensiling methodology on grass silage effluent production. Journal of Agricultural Engineering Research, v.60, n.1, p.7381, 1995.

KUNG JUNIOR, L.; GRIEVE, D.B.; THOMAS, J.W.; HUBER, J.T. Added ammonia or microbial inoculant for fermentation and nitrogenous compounds of alfalfa ensiled at various percents of dry matter. Journal of Dairy Science, v.67, p.299-306, 1984.
LICITRA, G.; HERNANDEZ, T.M.; VAN SOEST, P.J. Standardization of procedures for nitrogen fractionation of ruminant feeds.Animal Feed Science and Technology, v.57, n.4, p.347-358, 1996.

McDONALD, P. The biochemistry of silage. New York: John Wiley \& Sons, 1981. 207p.

McDONALD, P.; HENDERSON, A.R.; HERON, S.J.E. The biochemistry of silage. New York: Chalcombe Publications, 1991.

PAHLOW, G.; MUCK, R.E.; DRIEHUIS, F.; OUDE ELFERINK, S.J.W.H.; SPOELSTRA, S. F. Microbiology of ensiling. In: BUXTON, D. R.; MUCK, R. E.; HARRISON, J.H. (Ed.). Silage science and technology. Wisconsin: American Society of Agronomy, Crop Science Society of America and Soil Science Society of America. 2003. p.31-94.

SIQUEIRA, G.R.; REIS, R.A.; SCHOCKEN-ITURRINO, R. P., PIRES, A.J.V., BERNARDES, T.F., AMARAL, R.C. Perdas de silagens de cana-de-açúcar tratadas com aditivos químicos e bacterianos. Revista Brasileira de Zootecnia, v.36, p.20002009, 2007.

SNIFFEN, C.J.; O'CONNOR, J.D.; VAN SOEST, P.J. A net carbohydrate and protein system for evaluating cattle diets: II- Carbohydrate and protein availability. Journal of Animal Science, v.70, p.3562-3577, 1992.

STATISTICAL ANALYSIS SYSTEM - SAS. The SAS System for Windows: version 8.02. Cary: SAS Institute, 2001. 
STEEL, R.G.D.; TORRIE, J.H.; DICKEY, D.A. Principles and procedures of statistes a biometrical approach. 3. ed. Boston: WCB McGraw-Hill, 1997. 666 p.

TABACCO, E.; PIANO, S.; CAVALLARIN, L.; BERNARDES, T.F.; BORREANI, G. Clostridia spore formation during aerobic deterioration of maize and sorghum silage as influenced by Lactobacillus buchneri and Lactobacillus plantarum inoculants. Journal of Applied Microbiology, v.107, p.1632-1641, 2009.

VAN SOEST, P.J.; ROBERTSON, J.B.; LEWIS, B.A. Symposium: carbohydrate metodology, metabolism, and nutritional implications in dairy cattle. Journal Dairy Science, v.74, n.10, p.3583-3597, 1991.

VAN SOEST, P.J. Nutritional ecology of the ruminant. 2.ed. Ithaca: Cornell University Press, 1994. 476p.
WADI A; ISHII, Y; IDOTA, S. Effects of cutting interval and cutting height on dry matter yield and overwintering ability at the estabilished year in Penisetum species. Plants Production Science, v.7, p.88-86, 2004.

WHITTENBURY, R; McDONALD, P; BRYAN-JONES, D.J. A short review of some biochemical and microbiological aspects of silage. Journal Science Food and Agricultural, v.18, n.4, p.441-444, 1967.

WINTERS, A.L.; WHITTAKER, P.A.; WILSON, R.K. Microscopic and chemical changes during the first 22 days in Italian ryegrass and cocksfoot silages made in laboratory silos. Grass and Forage Science, v.42, p.191-196, 1987.

Data de recebimento: 24/11/2013

Data de aprovação: 19/09/2014 